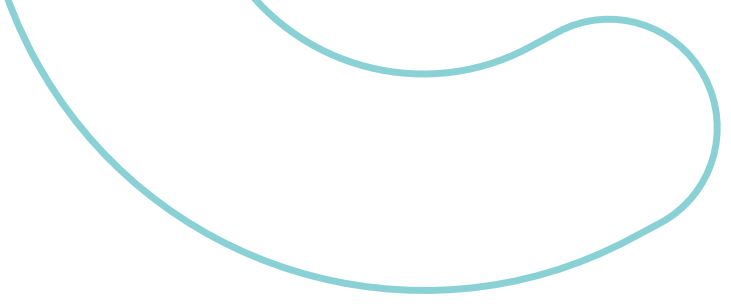

\title{
Systemic models as optimization tool for territory design:
}

\section{Case study}

\section{Bernabé Hernandis}

Universitat Politècnica de València

bhernand@upv.es

at

Iñaki Esnal

Universitat Politècnica de València

Miguel Angel Agustín

Universitat Politècnica de València

\section{Angelly Joana Arzuza}

Universitat Politècnica de València

\section{Diana Arévalo}

Universitat Politècnica de València

PROJËTICA

\section{COMO CITAR ESTE ARTIGO:}

HERNANDIS, Bernabé et al. Systemic models as optimization tool for territory design. Case study. Projética, Londrina, v. 11, n. 3, p. 45-69, Nov. 2020. Edição especial. FDaP. DOI: 10.5433/2236-2207.2020v11n3esp.p45. ISSN: 2236-2207.

DOI: 10.5433/2236-2207.2020v11n3esp.p45

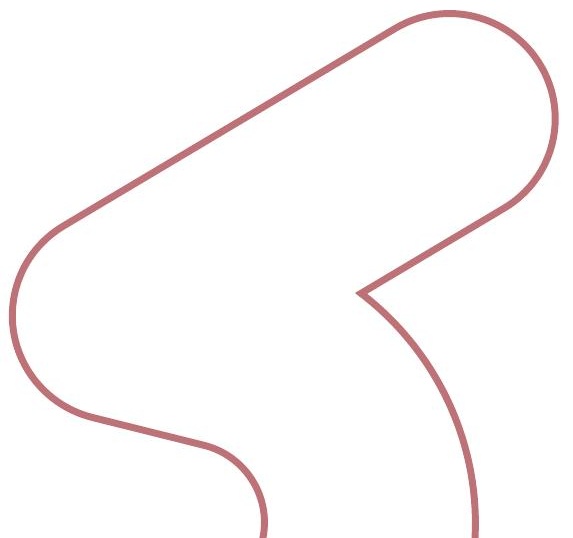


ABSTRACT: The objective of this research is the optimized design of the territory with respect to the sustainability of systems belonging to the "new rurality", based on action research, through the use of systemic models, which intend to carry out a design of the territory, according to the use of the new technologies and with the consideration of the socioeconomic and technical aspects of local development. For this, two cases belonging to the Colombian territory have been studied, in matters related to emerging systems of the territory. The use of systemic models has enabled the approach and simulation of the models, which represent the territory and therefore of decision-making, which allow the optimization of available resources in units considered as sustainability modules. The initial results suggest the extraction of knowledge necessary for systemic implementation. The results obtained allow the achievement of objectives and their final representation

Keywords: Territory design local development. Systemic methodologies. Knowledge Management. Models.

\section{INTRODUCTION}

Systemics as a metalanguage has demonstrated the utility of the application of its models, in the Operational and Systems Research School of the University of Valencia (1965-1991). The works developed in this institution are innumerable, being numerous the works oriented to the design of the territory. Systemics, according to Hernandis (2003), is defined as "the science that studies the systems and the knowledge necessary to represent reality, through the use of a metalanguage, based on the application of the General Systems Theory. With it, we can build a mental structure capable of representing any event, regardless of its origin or genesis, being a social, conceptual, natural, technological or any other nature, whether tangible or intangible; this definition being applicable to all systems in general". 
This implies that for its study it is necessary to research and analyse the subsystems that constitute the fundamental factors involved in the design of the territory, establishing that subsystems of the nearby environment, determine influences to be considered in the design of the product/service under study. The systemic models facilitate, in this way, the integration in the heterogeneous consideration of the different intervening subsystems from the different aspects to consider in the design of the territory.

The Objective Formulation Model (MARTÍNEZ DE LEJARZA Y ESPARDUCER; HERNANDIS-ORTUÑO; LAHIGUERA MARCO, 1994) has allowed, over time to represent any type of system considering its implementation in the territory, from the necessary "n-dimensionality" that the complexity of knowledge management currently requires.

The experience accumulated in the implementation of the models (19842019) has allowed us to adapt to any of the approaches raised from the academy and addressed since teaching, by subjects such as "Modelling of systems oriented to the management of knowledge in industrial design", which has been taught in the last decade in the Master in Design Engineering, of the Higher Technical School of Engineering in Design at the Universitat Politècnica de València. Likewise, since 1994, several training actions were carried out, such as the Thematic Design Networks financed by AECID, as well as its own title called Master of Design, Management and Development of New Products of the UPV (1998-2019). In these actions the models have been part of the academic content, being usual tools of various subjects for systemic modelling, to form a database of Thesis and Final Master's Projects with more than 200 monographies. Doctoral theses have also been developed, oriented in the aspects of the aforementioned Systemic Modelling. We could say that a large part of these works have represented reality designing knowledge, which in turn designs the territory. It is important to highlight the dissemination of these models, due to the wide internationalization of the aforementioned titles, since they cover 
the European continent: Spain, Italy, Germany, Holland, Norway, Sweden, Greece, Turkey, Poland, France, Russia, Ukraine, England, Belgium, among others. And in America: Chile, Argentina, Uruguay, Venezuela, Portugal, Brazil, Mexico, Ecuador, Dominican Republic, Costa Rica, Paraguay and Peru.

It is clear that this review aims to visualize the importance of systemic models as an indisputable tool, which has the capacity to adapt to any of the circumstances, in which the application of the design and in particular the design of the territory is necessary. The analysis of the "System under study" as well as its immediate surroundings, are perfectly defined by representing its main integrating sub-systems and also the supra-systems of its nearby special relevance environment.

Likewise, the methodology allows to represent not only the territory and its environment, but also to consider the relationships, which among the subsystems represented exist considering, therefore, the study of feedback loops which determine the variations in the behaviour of the subsystems that it's made of.

Fig. 1 - Input and output information flow.

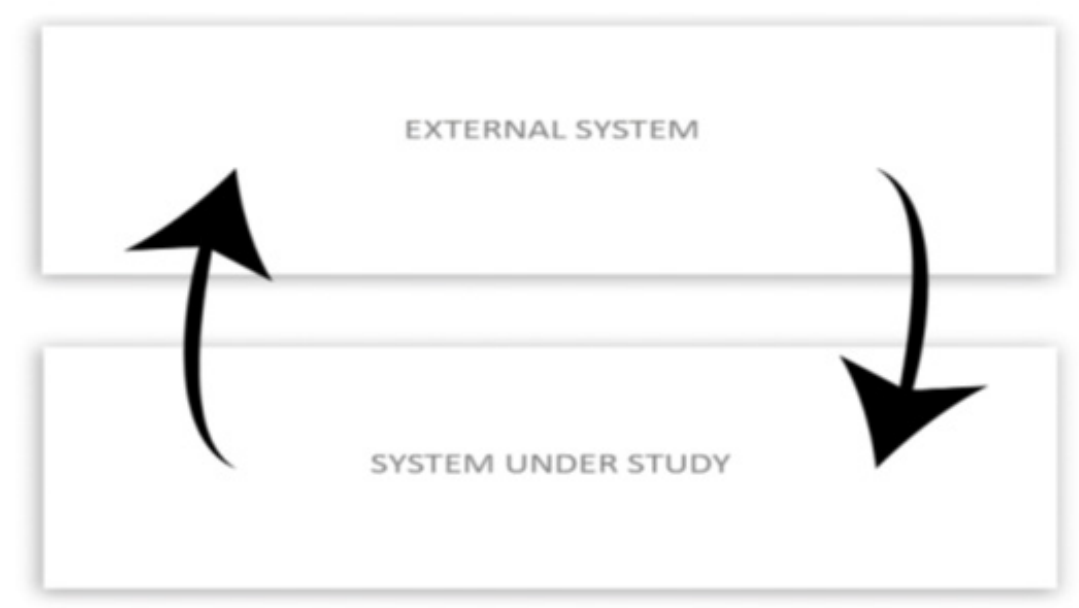

Font: Hernandis-Ortuño, Agustín-Fonfría e Esnal-Angulo (2017). 
The models developed so far have allowed us to analyse the social, economic, technical and political aspects, based on the indicators that determine the basic needs of the inhabitants distributed in the territory. The modelling allows us, therefore, its dimensioning from the heterogeneous conceptual analysis, which requires the consideration of the measure of each of the aspects that make up the territory, forming differentiated subsystems from the aforementioned considerations.

The work carried out in Doctorate and Master programs, have allowed us to verify the internationalization of design, since they have mostly been developed by students from Latin America, and only in the last decade can we observe a notable increase in European students, which sets a trend. So far the studies addressed in this diversity of countries have allowed us to demonstrate the growing interest in its application in any type of casuistry in regard to the design of the territory. It has worked both the design of the environment, as well as the social, economic and technical organization that society demands from its development (UPV General Library, ETSID-UPV Library, DIGD Office, rDis Office).

Emerging systems are usually the configuration of the territory. The systemic, based on the use of knowledge management through systemic models, aims to coordinate and optimize the resources that are necessary for the sustainable exploitation of the territory.

From the academy, a continuous effort is made in the achievement of these objectives and the transfer of knowledge as a contribution to the design of the territory. The investigation continues for the sake of the optimization commented of the territory, has allowed us to approach the search for the design of "optimized sustainable systems" as a desirable goal. 


\section{METHODOLOGY}

We are currently in the process of investigating two case studies, raised in the Colombian territory. Both investigations have their origin in works developed by the students of Master in Design Engineering, Angelly Joana Arzuza Lamadrid and Diana Arévalo Gómez. The application of systemic models in these two cases is studied, for the design of the territory in Colombian communities.

The specific theme refers to:

Case 1. Design of a vertical modular fruit and vegetable farm, for the supply of indigenous communities in Colombia.

Case 2. Design of a system for collecting, filtering and pumping rainwater for areas of the tropics under Colombia.

The objective will be the Optimized Design of these systems, adapted to their immediate environment considering the aspects that influence the most significant supra-systems and the subsystems and influence variables that affect them.

In order to carry out the systemic methodology, we applied the ID-Think student version model (HERNANDIS-ORTUÑO; AGUSTÍN-FONFRÍA; ESNAL-ANGULO, 2017) in which we proceed to the extraction of knowledge in the first instance, through the application of qualitative techniques for the analysis of influence factors, Fig.2.

We performed a Brainstorming, Googlestorming, Concept maps, Comparative matrices and Positioning maps in order to conclude the synthesis of knowledge (HERNANDIS; CABELLO, 2013). In a second stage we proceed to analyse by the Objectives Formulation Model (MARTíNEZ DE LEJARZA Y ESPARDUCER; 
HERNANDIS-ORTUÑO; LAHIGUERA MARCO, 1994), applied to each of the cases, resulting in a systemic feedback model, which provides us with tailored solutions and that are revisable throughout the time, depending on the degree of compliance with the objectives set.

Fig. 2 - External System panel. ID-Think Model, Student version

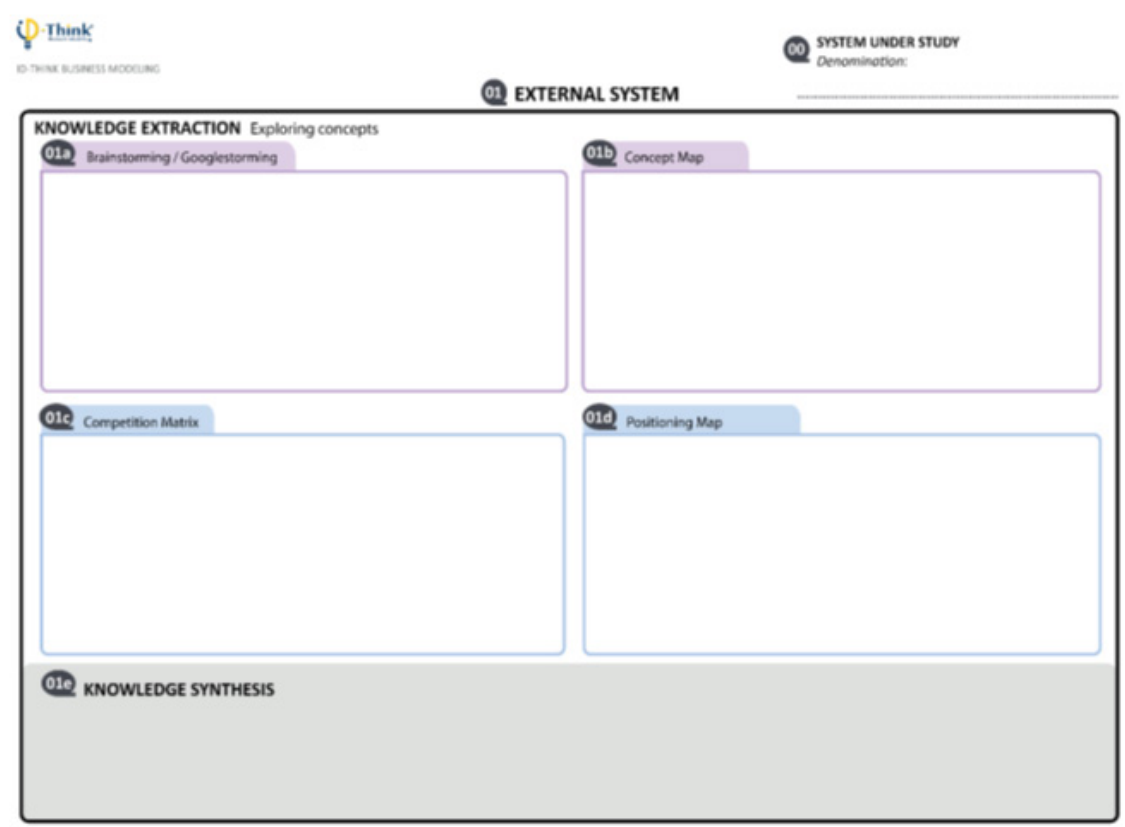

Font: Hernandis-Ortuño, Agustín-Fonfría e Esnal-Angulo (2017).

The Fig 3, represents the Model of Objective Formulation, which will allow us the simulations that we want to perform in order to achieve the desired objectives. ecessary to overcome a contemplative perspective of the territory, in order to adhere to a creative vision, linked to the digital dimension of the contemporaneity, capable of overcoming the homogenization imposed by a globalized flattening of differences. 
Fig. 3 - System Under Study panel. ID-Think Model, Student version

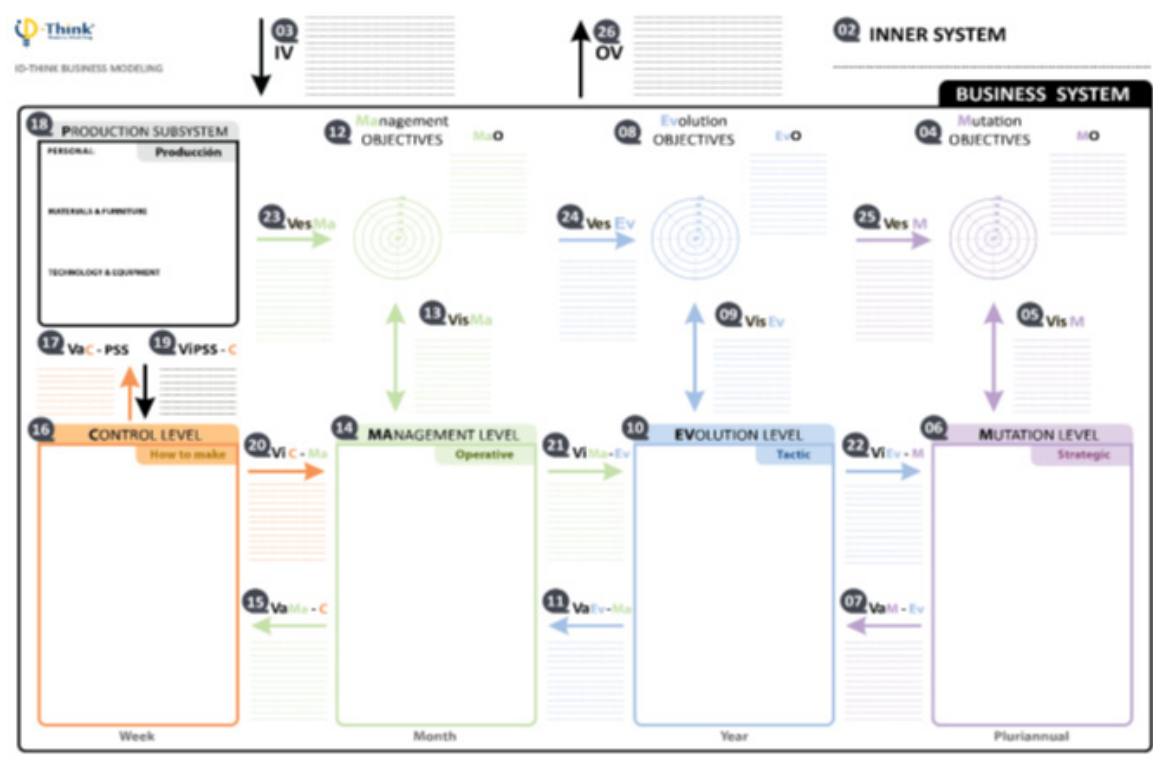

Font: Hernandis-Ortuño, Agustín-Fonfría e Esnal-Angulo (2017).

\section{RESULTS}

Since the research is in the knowledge extraction phase and the beginning of the model implementation phase, the implementation and simulation phase of proposals cannot be reached at this time.

Therefore, it is intended to present the results exclusively from the initial phase, postponing the validation, for the presentation of the presentation at the congress if deemed appropriate. 


\section{Case 1:}

\section{Brainstorming:}

Table 1 - Results of the Brainstorming application

\begin{tabular}{llll}
\hline Vertical Farm & Food & Community & Energy \\
\hline Hydroponics & Nutrition & Population & Renewable energies \\
Cultivation & Self-supply & Social innovation & Efficiency \\
Harvest & Consumption & Culture & Reuse \\
Modularity & Diet & Culture & Adaptation \\
Materials & & & \\
\hline
\end{tabular}

Font: Authors.

The results, object of the methodological application of this tool, led us to detect the areas of interest and guide research.

\section{Googlestorming:}

Fig. 4 - Food. Result of the Googlestorming application

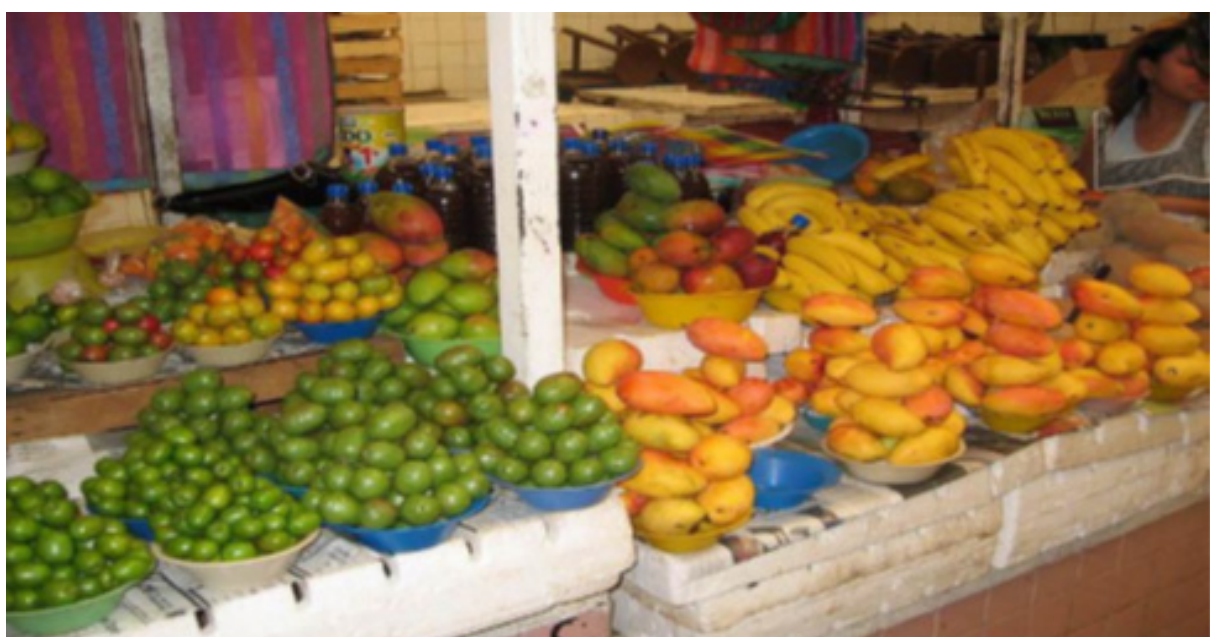

Font: (ONE MAN'S..., 2013). 
Fig. 5/6 -Hydroponics. Result of the Googlestorming application

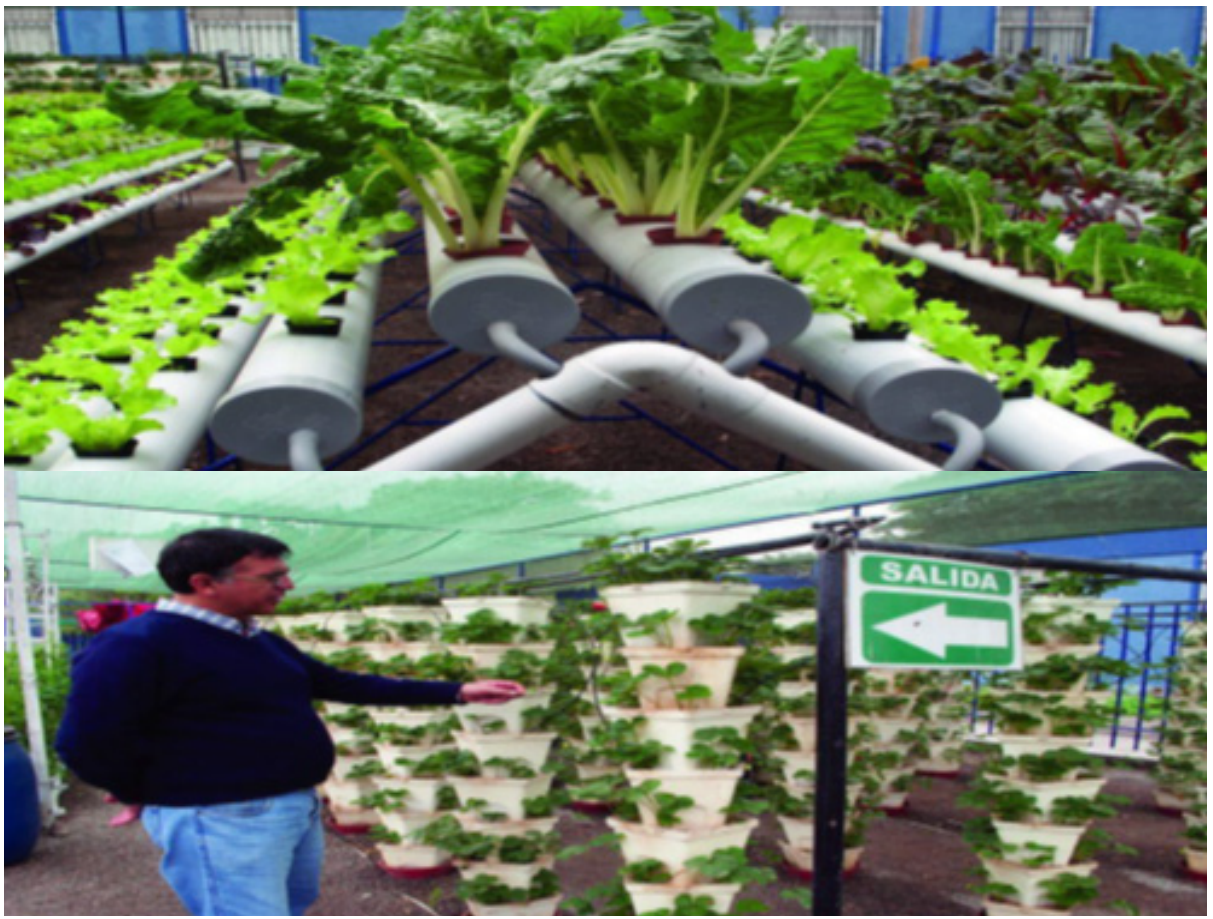

Font: Ortiz (2017).

Fig. 7 - Community. Result of the Googlestorming application

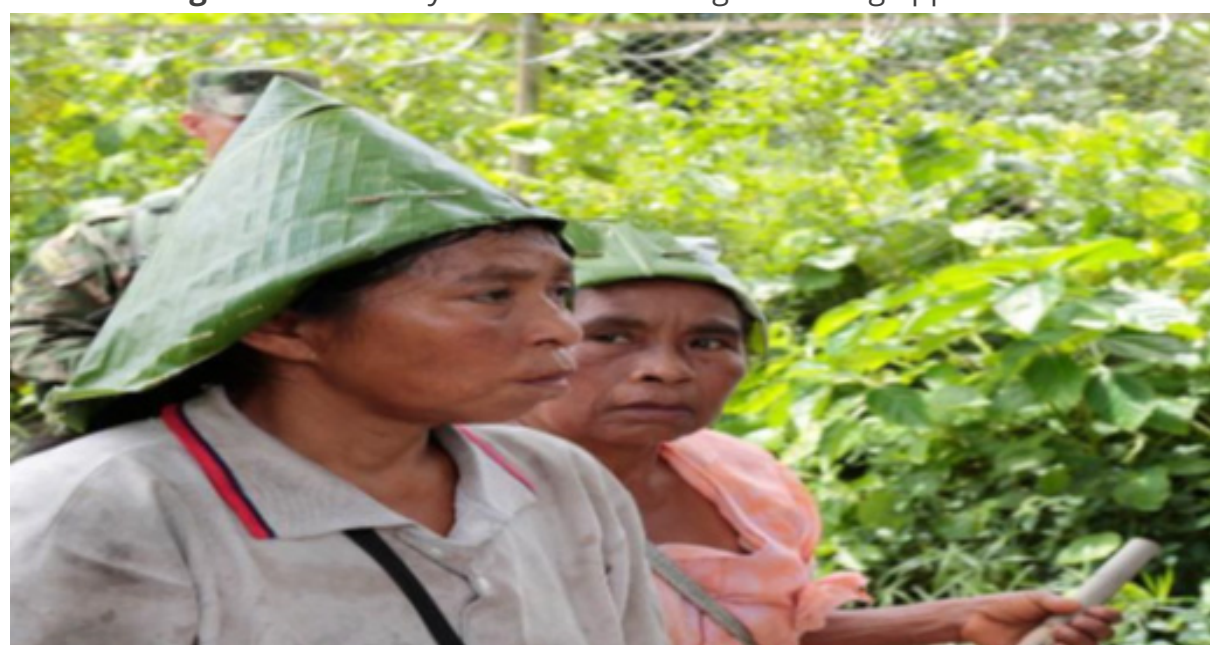

Font: Hernández (2017). 
Systemic models as optimization... Case study

HERNANDIS, Bernabé et al.

Fig. 9 - Energy. Result of the Googlestorming application

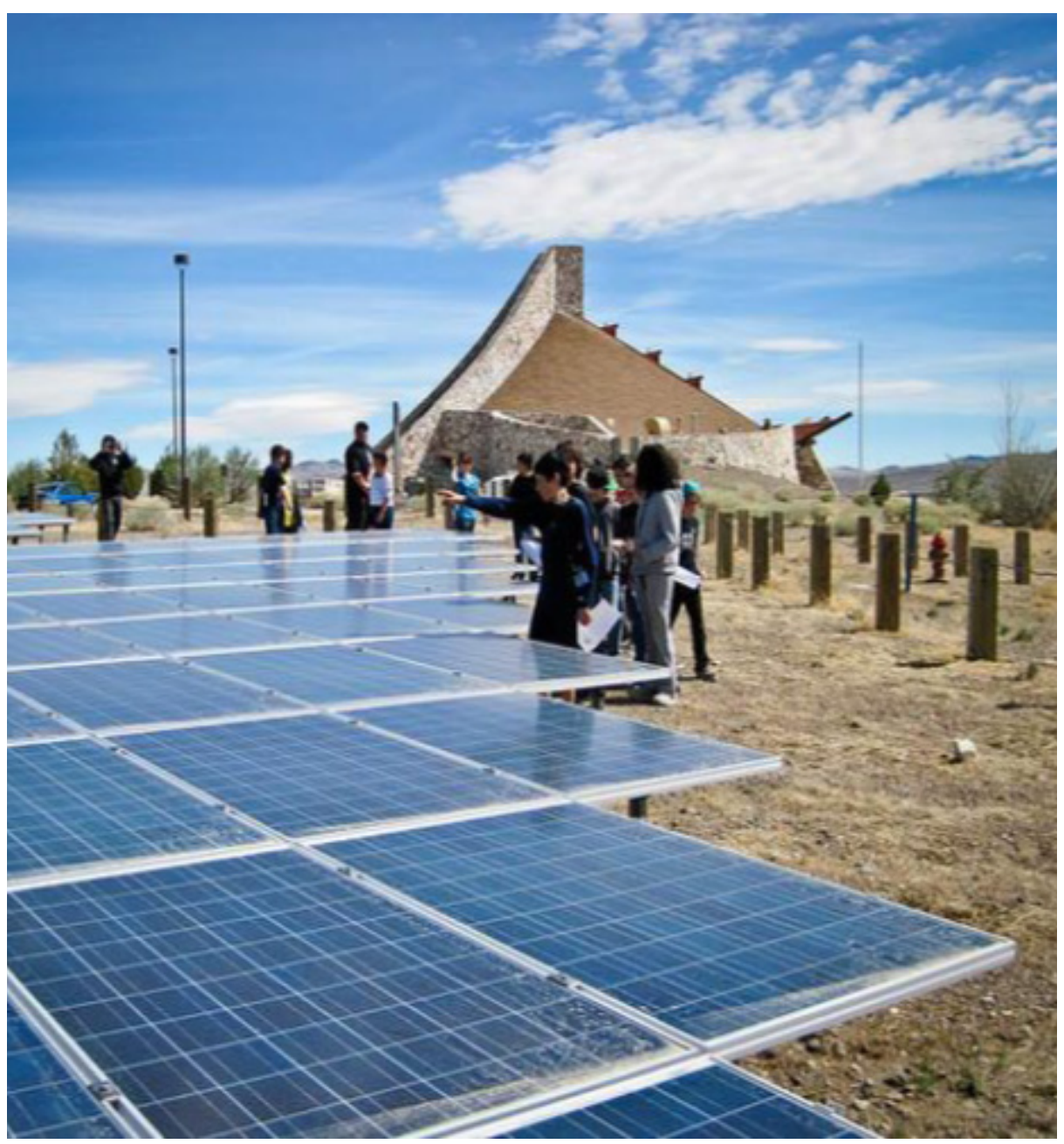

Font: Black Rock Solar (2012). 
Projética, Londrina, v. 11, n. 3 Esp IFDaP, p. 45-69, novembro 2020

Fig. 8 - Vertical farm. Result of the Googlestorming application

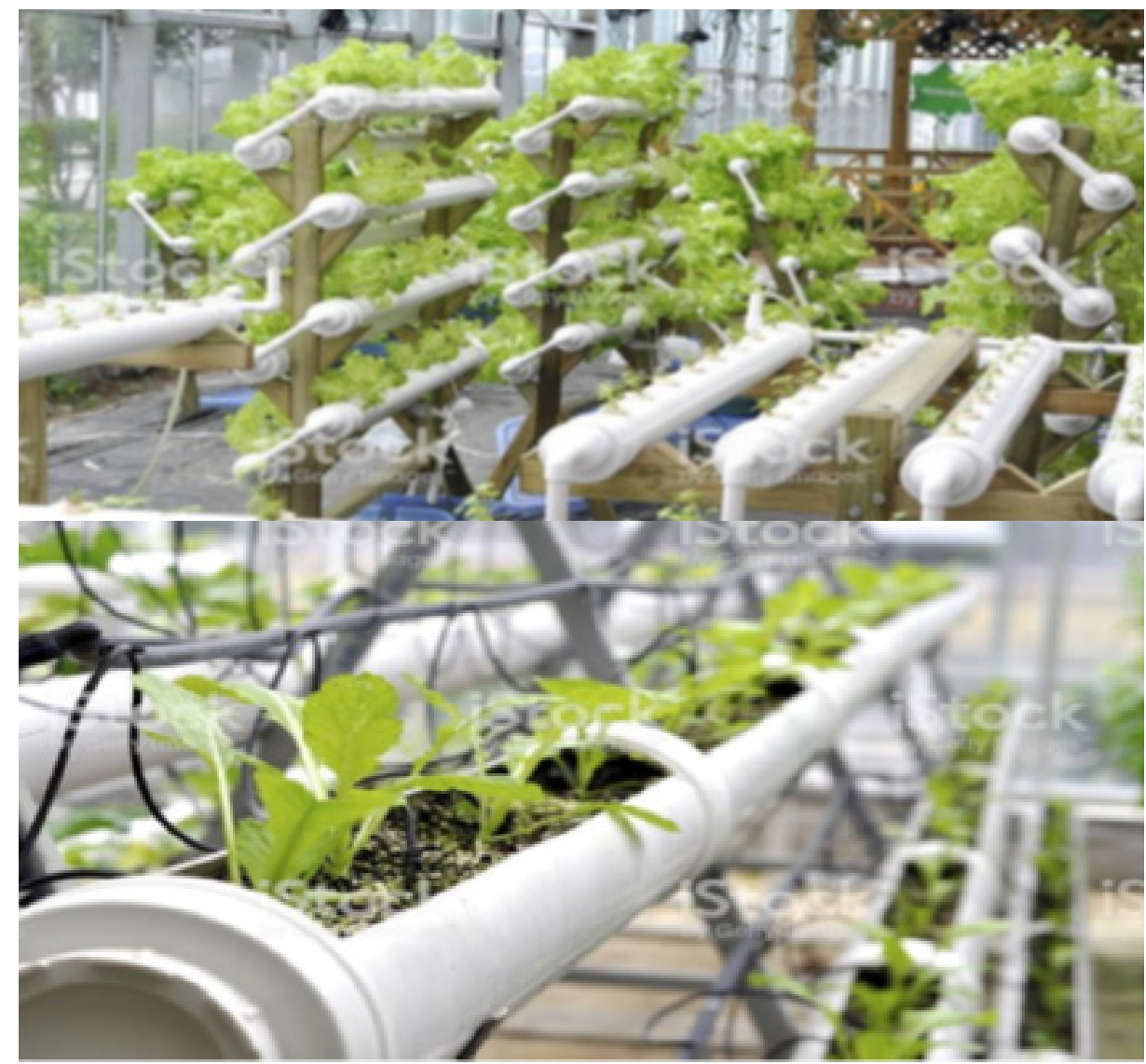

Font: Momokey (2013).

The Googlestorming showed us pictures illustrating part of the objectives to be considered and pointed solutions, already used to the issues raised. 


\section{Concept Map:}

Fig. 10 - Vertical farm. Result of the Googlestorming application

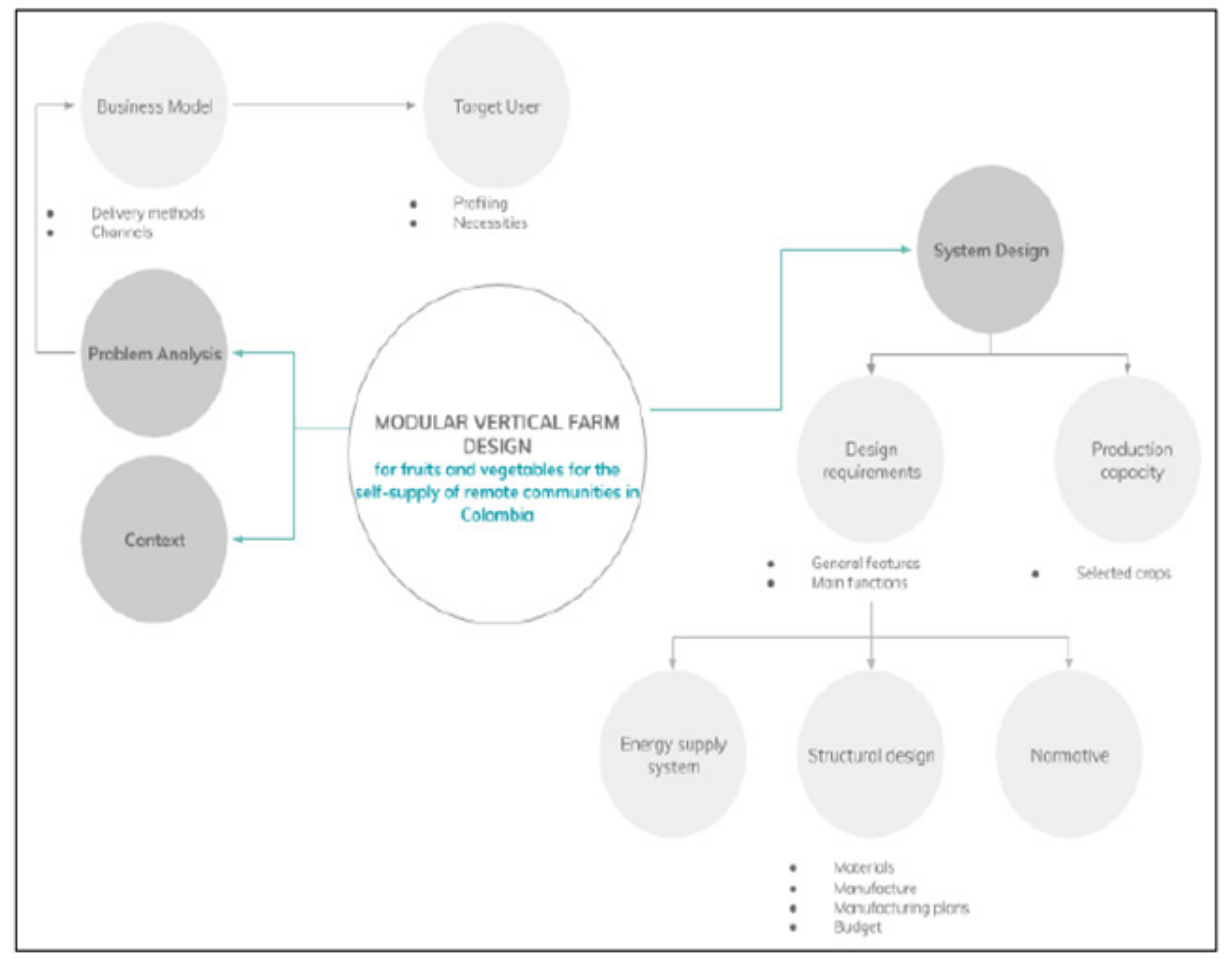

Font: Authors.

The concept map centered the problem around the most important factors to consider from the social, technical, productive aspects, etc. 


\section{Comparative matrix}

Fig. 11 - Result of the Concept map application.

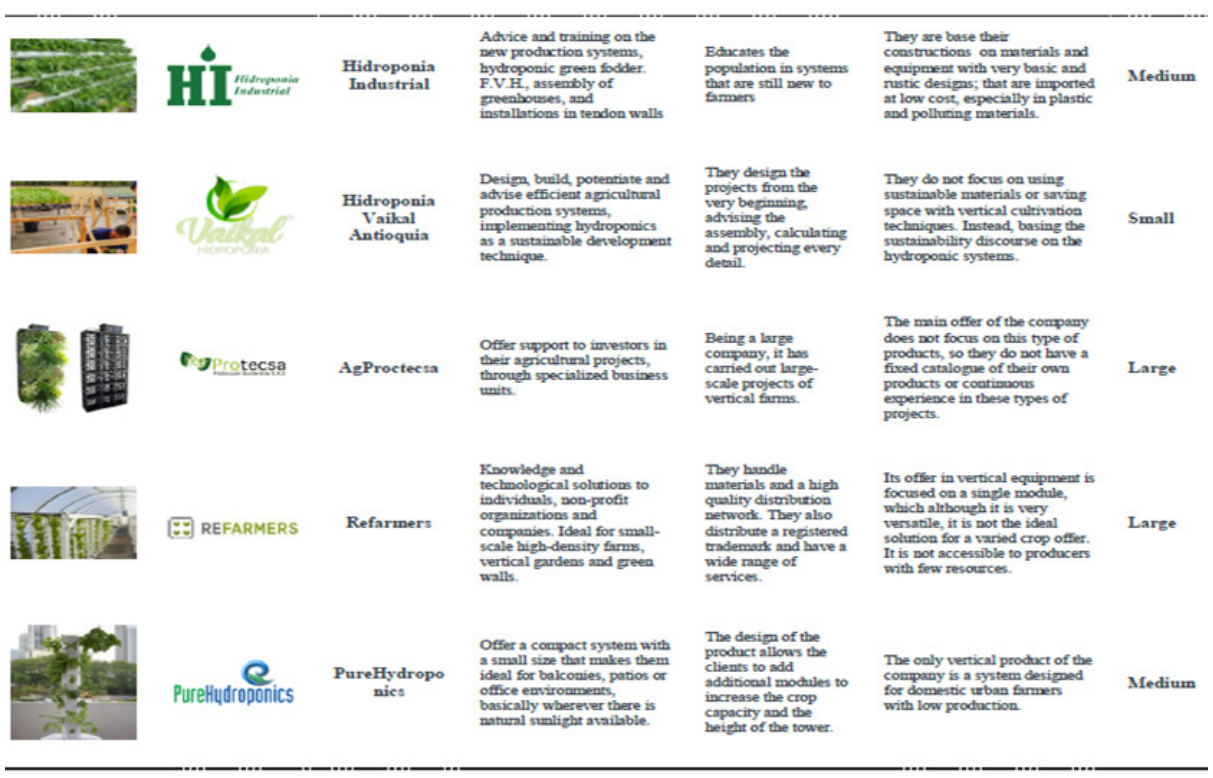

Font: Authors.

The previous matrix carries out a comparative analysis between the most significant aspects to consider in existing systems that solve the specific problem addressed, giving diverse solutions with different costs and service qualities.

Following the methodology described in the ID-Think application, the search for gaps was proposed, using the technique of positioning maps of the companies or systems selected in the Comparative Matrix.

Several aspects were analyzed compared two to two, obtaining different graphs as a result of the selected variables. 
Positioning map:

Fig. 12 - Quality vs. Functionality. Result of the Comparative map application

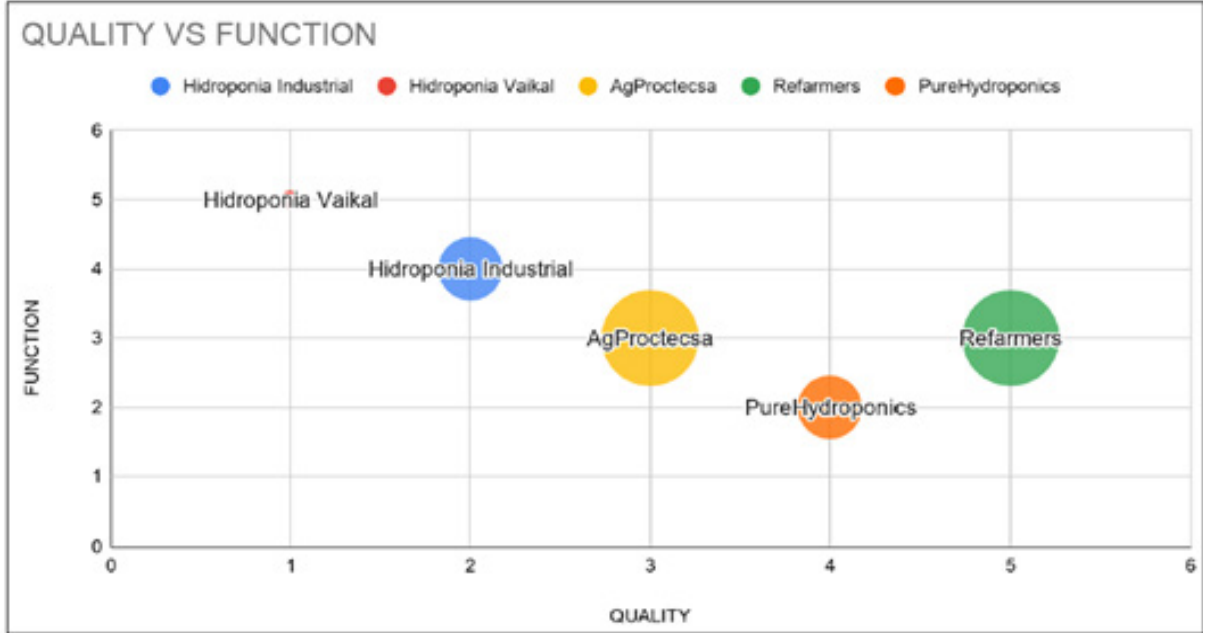

Font: Authors.

Fig. 13 - Technology vs. Experience. Result of the Comparative map application.

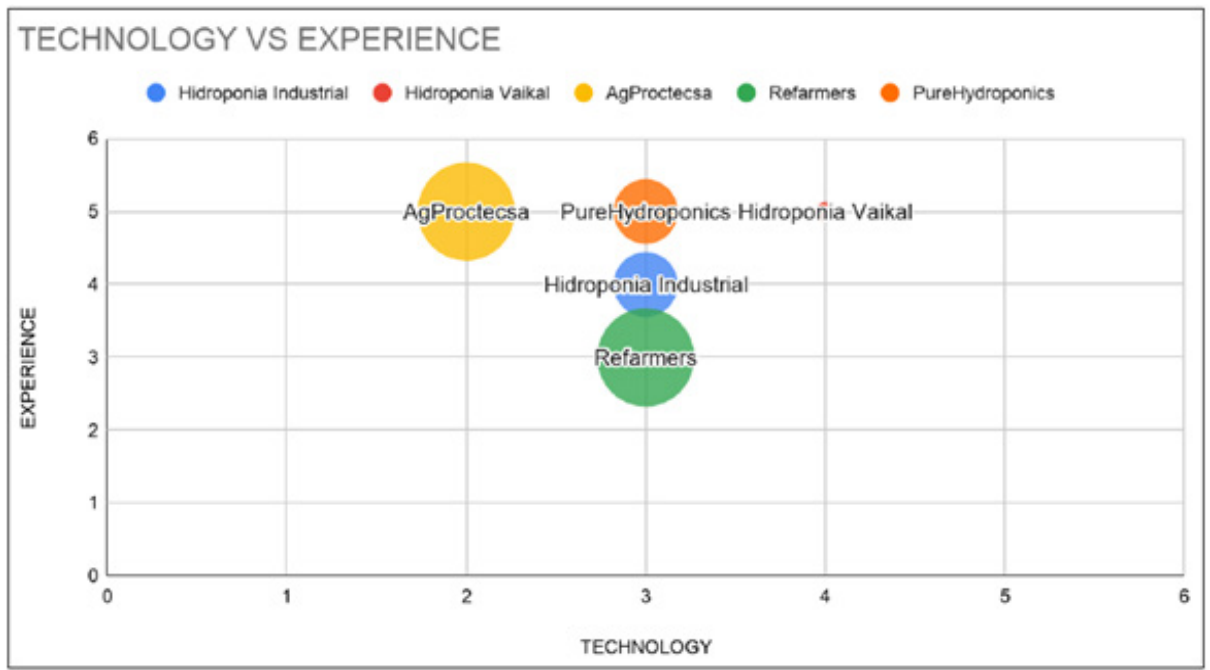

Font: Authors. 
Projética, Londrina, v. 11, n. 3 Esp IFDaP, p. 45-69, novembro 2020

Fig. 14 - Profitability vs. Production. Result of the Comparative map application.

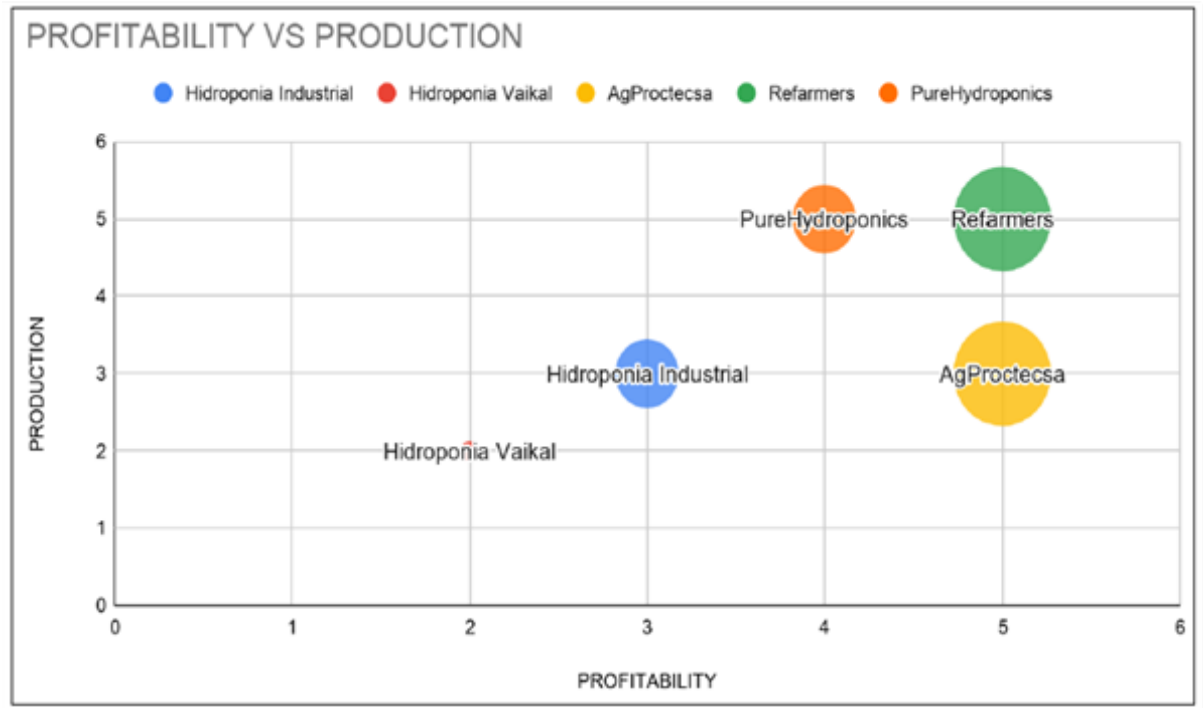

Font: Authors.

With this we can study where we should position our service proposal that can tend to the needs described above, thereby modeling a proposal of Organizational Design adapted to the territory under study, in Colombia.

\section{Case 2:}

As in case 1 and by reiteration of the ID-THINK methodology, we will repeat the analysis in the previous case. 


\section{Brainstorming:}

Table 2 - Results of the Brainstorming application. Case 2.

\begin{tabular}{|c|c|c|c|}
\hline $\begin{array}{l}\text { Reduction of } \\
\text { environmental impact }\end{array}$ & Resource reuse & Collectors & Precipitation \\
\hline Climate change & Use of rainwater & Containers & Sun brightness \\
\hline Sustainability & $\begin{array}{l}\text { Use of solar } \\
\text { energy }\end{array}$ & $\begin{array}{l}\text { Ground } \\
\text { conditions }\end{array}$ & Clean production \\
\hline $\begin{array}{l}\text { Intervention in } \\
\text { products and } \\
\text { processes or Tropic } \\
\text { under Colombian }\end{array}$ & $\begin{array}{l}\text { Water } \\
\text { purification }\end{array}$ & $\begin{array}{l}\text { Weather } \\
\text { conditions }\end{array}$ & $\begin{array}{l}\text { Small and medium farmers, } \\
\text { Colombian Federation of Livestock } \\
\text { Farmers (FEDEGAN), Ministry of } \\
\text { Agriculture and Rural Development, } \\
\text { Colombian Agricultural Institute (ICA), } \\
\text { Ministry of Environment, City Halls } \\
\text { and governorates }\end{array}$ \\
\hline
\end{tabular}

Font: Authors.

The results object of the methodological application of this tool led us to detect the areas of interest and guide research

\section{Googlestorming:}

Fig. 15 - Dew Water Collection System. Result of the Googlestorming application

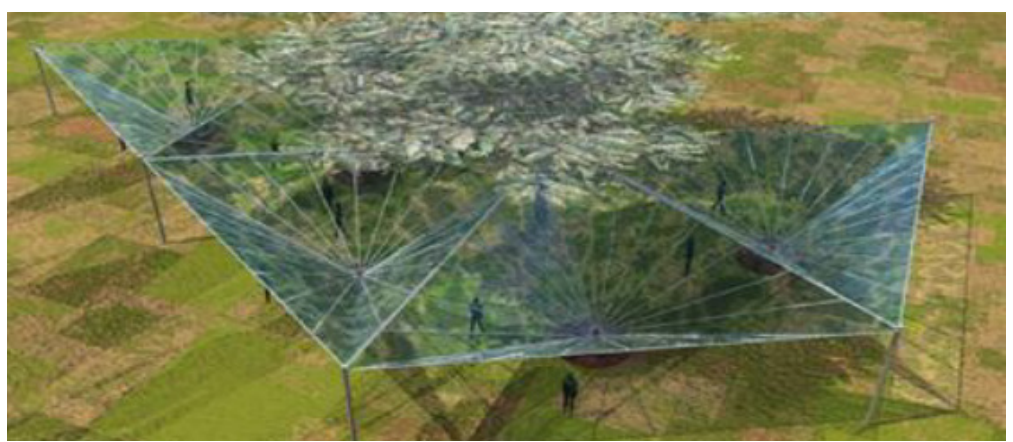

Font: Geotectura (2019). 
Fig. 16 - Concave Roof System Collects Rainwater. Result of the Googlestorming application

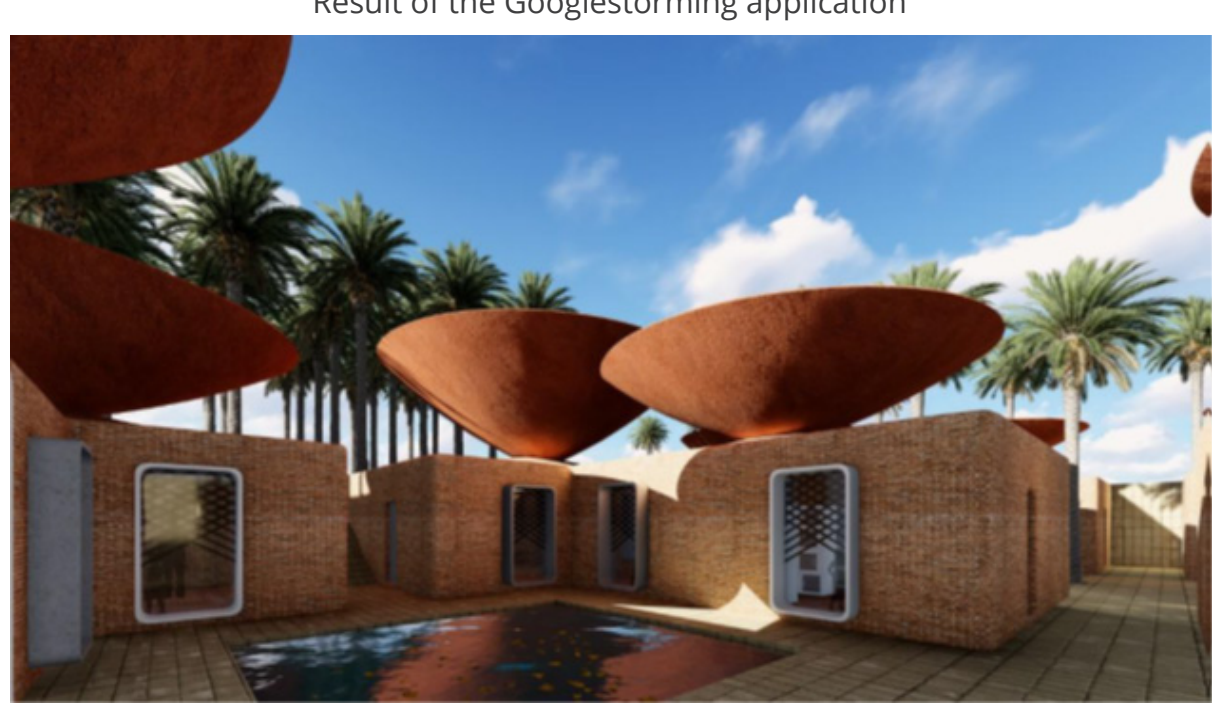

Font: (BMDESIGN..., 2019).

Fig. 17 - Bombeo solar para ganadería. Result of the Googlestorming application

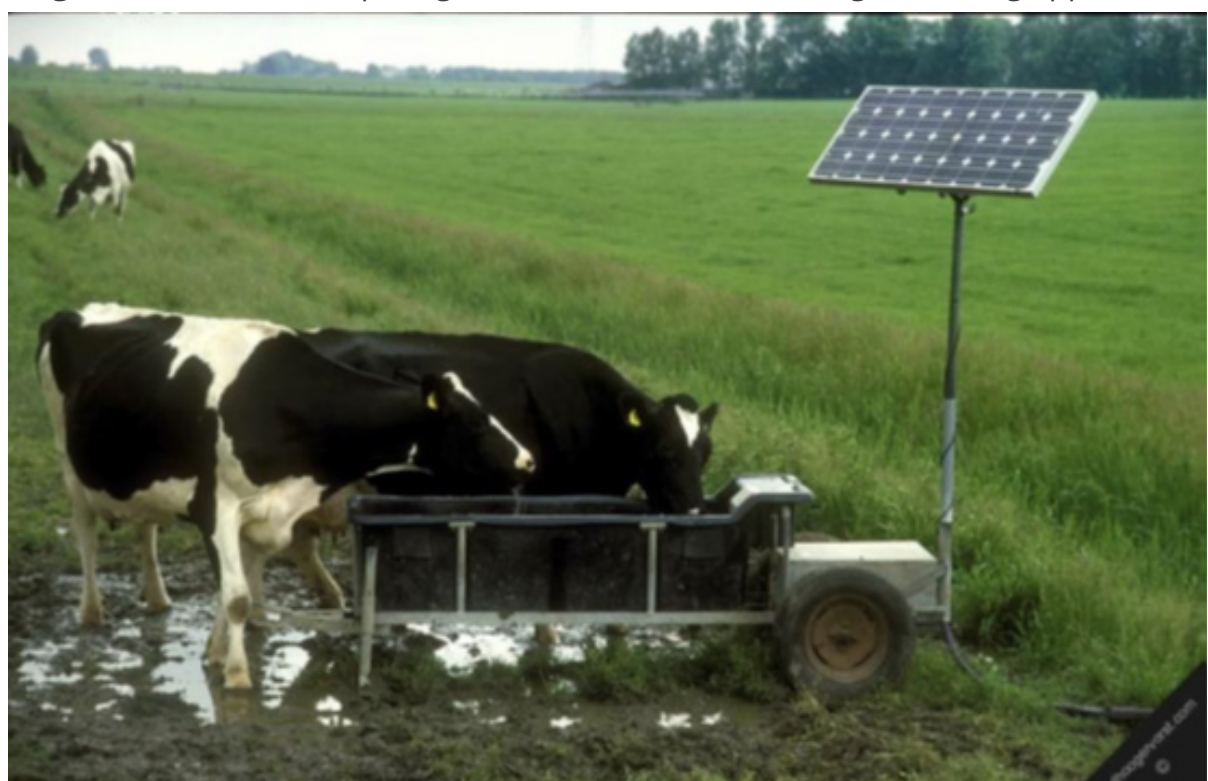

Font: Astrotekecuador (2019). 
The Googlestorming, showed us that images illustrated part of the objectives to consider and pointed out solutions, already used for the problem raised.

\section{Concept Map:}

Fig. 18 - Result of the Concept map application. Case 2.

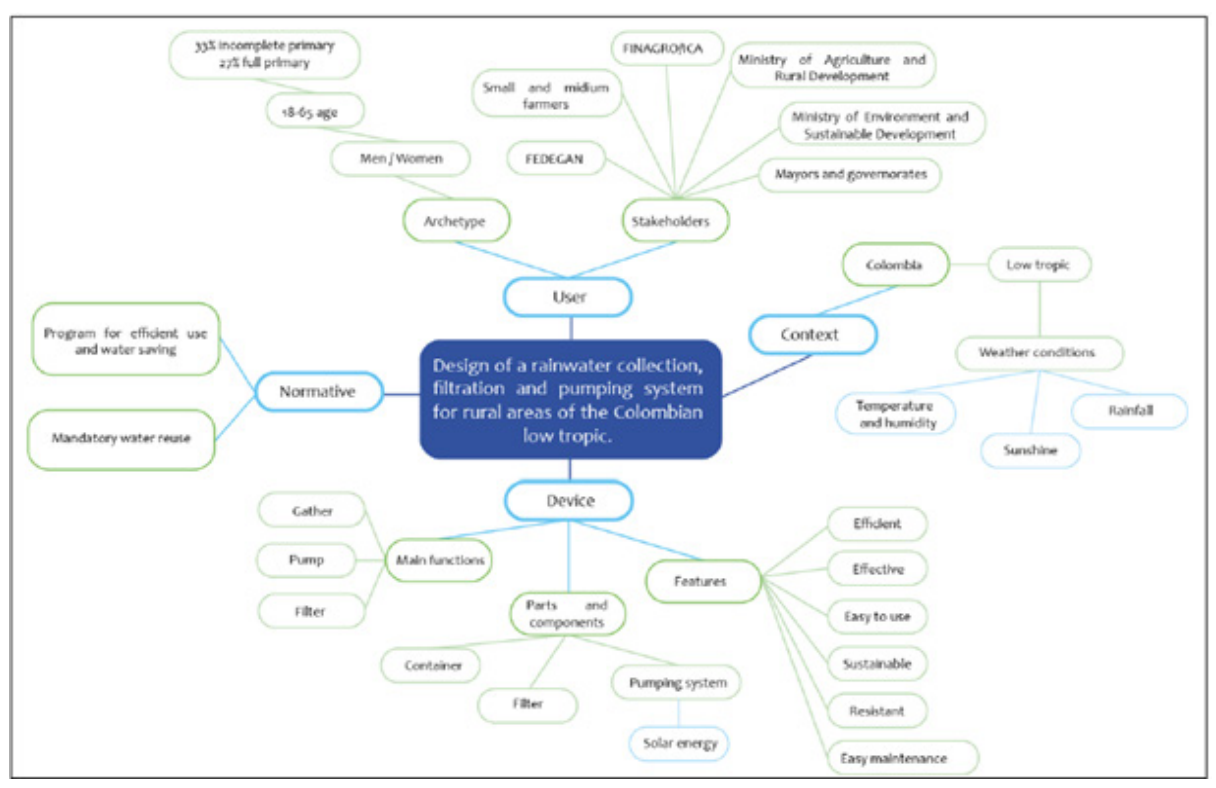

Font: Authors.

With the Googlestorming we define the main areas of interest around the problem raised. 


\section{Comparative matrix:}

Table 03 - Result of the Comparative matrix application. Case 2.

$N^{*}$

1

Imoge
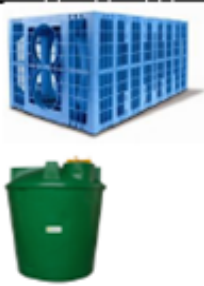

3

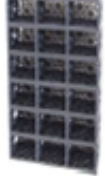

Sistemas urbanos

Drenaje Sostenible

S.l

Domio Solor

a bortes PS1800 Cus 10

4

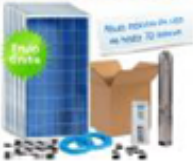

5

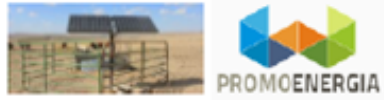

6

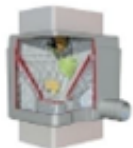

\section{Damia Solar}

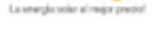

PROMOENERGIA

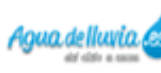

$\begin{array}{ll}\text { Country } & \text { Product/Service } \\ \text { Mexico } & \text { Storager system } \\ & \text { Filter }\end{array}$

Colombia Storage tanks

Advice

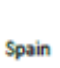

Spain

Drainage network design

Advice

Rainwater harvesting Focusing on water using permeable surfaces harvesting from city streets

Rainwater infiltration, Rainwater infiltration, They work with big storage; hydrological companies and cities. analysis and advisory Focus on rainwater service storage

Tanks of different
volumes advising on
tank installation

They only offer

storage tanks

The largest storage volume is 3,000 liters

$\begin{array}{lll} & \begin{array}{l}\text { Works with solar } \\ \text { power and no } \\ \text { Spain } \quad \text { Kits for pumping } \\ \text { and irrigation }\end{array} & \begin{array}{l}\text { be installed by user } \\ \text { advisories }\end{array}\end{array}$

\begin{tabular}{llll} 
& & \multicolumn{3}{c}{$\begin{array}{l}\text { Works with solar } \\
\text { energy }\end{array}$} & \\
Colombia & Photovoltaic kits & $\begin{array}{l}\text { It works with } \\
\text { Renewable } \\
\text { energy plants }\end{array}$ & $\begin{array}{l}\text { Very expensive } \\
\text { Designed specifically } \\
\end{array}$ \\
& & for rural areas &
\end{tabular}

Underground

tanks External Design tanks and

tanks filters

Flexible tanks

Rain filters

Flexible tanks optimize space
They only design tanks, their designs are general

Font: (ONE MAN'S..., 2013).

Conclusions: With the matrix we compare the different existing systems in the market, oriented to the solution or solutions sought. And again the positioning map discovered where these solutions were located with respect to the variables studied and compared. 


\section{Positioning map:}

Fig. 19 - Result of the Positioning map application. Case 2.

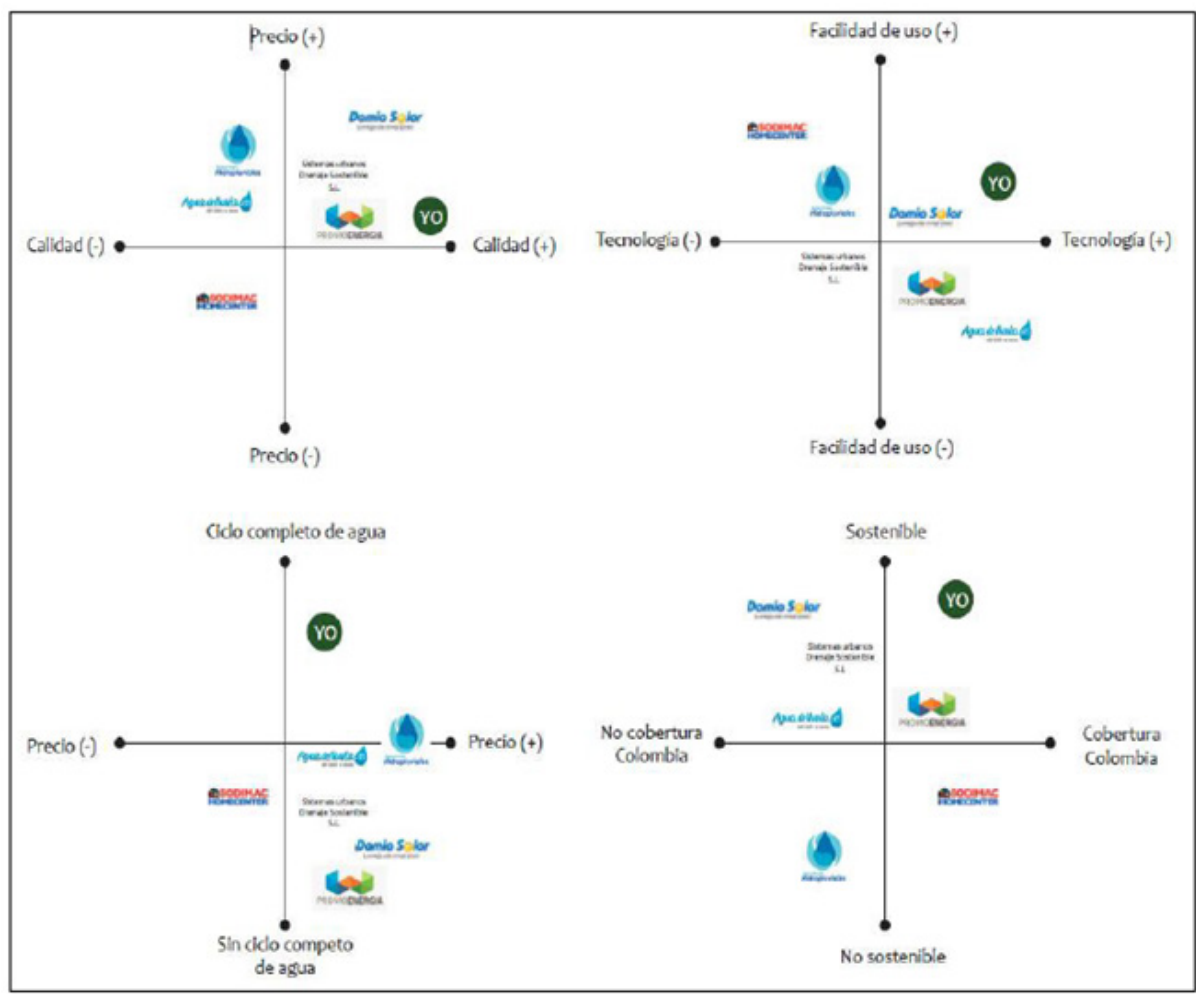

Font: Authors.

Once the results of the first phase of application of the ID-Think models have been presented (HERNANDIS, 2017), we will discuss them.

Given the preliminary nature of the study, the modeling of the organization for optimized case management is being carried out in the territory that has been part of the study. 


\section{DISCUSSION}

The systemic models allow, through action research, to generate multiple simulation processes based on the proposed objectives, which translates into the possibility of observing what the simulated result would be and anticipating different scenarios and responses, depending on the different degrees of compliance of the proposed objectives.

It is obvious, that being a qualitative process initially, can lead to errors depending on the initial hypotheses raised and the degree of specificity or accuracy of the indicators used. On the other hand, given its low cost as they are theoretical simulations, it allows adjusting the proposed objectives. Being able at all times to adapt to the observed disturbances. Any deviation will be easily corrected, when identified quickly, due to transparency in the representation and visualization of the system and its behavior.

\section{CONCLUSION}

The systemic models are a powerful tool in the design of the territory, since they are perfectly scalable to any magnitude of the system to be represented, and their systematic implementation, allows to address with order and temporary programming, the approach of any representation of the territory, both for neophytes and for experts if they require it.

We can therefore conclude that in the initial phase of the cases studied both the presentation and the implementation process guarantees results that can be assessed from the qualitative and quantitative order. 


\section{Systemic models as optimization... Case study \\ HERNANDIS, Bernabé et al.}

The possibility of keeping the model alive, based on providing indicators and observing at all times its effectiveness, with respect to the objectives set, confer a strength against other more complex procedures and / or tools.

The conceptual management infers ease of use, while its representation through feedback loops gives added value in the quantification of the concepts if it is desired that other, simpler tools do not consider.

At present we can mention that part of the investigation resulting from the application of the ID.THINK model that completes the use of the methodology applied in the preliminary phase of this article, is in the finalization phase. Currently in Public Exhibition. 


\section{BIBLIOGRAPHY}

1. ASTROTEKECUADOR. Bombeo solar para ganadería sustentable en América Latina. 2019. Available at: http://www.astrotekecuador.com/aplicaciones. html. Access in: 11 Jul. 2019.

2. BLACK ROCK SOLAR. Black rock solar educational field trip at Pyramid Lake Museum and Visitor Center. 2012. Available at https://www.flickr.com/ photos/39145569@N07/8553361852. Access in: 11 Jul. 2019.

3. BMDESIGN studios. Concave roof system collects rainwater. 2019. Available at: https://www.archdaily.com/802377/this-concave-roof-system-collectsrainwater-in-arid-climates. Access in: 10 Jul. 2019.

4. GEOTECTURA. Dew water collection system. 2019. Available at: https:// neofronteras.com/?p=892. Access in: 10 Jul. 2019.LAWSON, Bryan R. How designers think: the design process demystified. 4th ed. Burlington, MA: Elsevier/Architectural, 2006.

5. HERNÁNDEZ, Johan Alexis O. Algo que aprender de los U 'Wa. 2017. Available at: http://evolutionline.com.co/evol/index.php/2017/10/19/algo-queaprender-de-los-uwa/. Access in: 11 Jul. 2019.

6. HERNANDIS, Bernabé; CABELLO, Marcela. Creatividad, innovación y desarrollo de nuevos productos. Valencia: Generalitat Valenciana, 2013.

7. HERNANDIS-ORTUÑO, Bernabé; AGUSTÍN-FONFRÍA, Miguel Ángel; ESNALANGULO, Iñaki. Modelo sistémico para la gestión de empresas. Valencia: Red Internacional de Investigación en Diseño Sistémico, 2017.
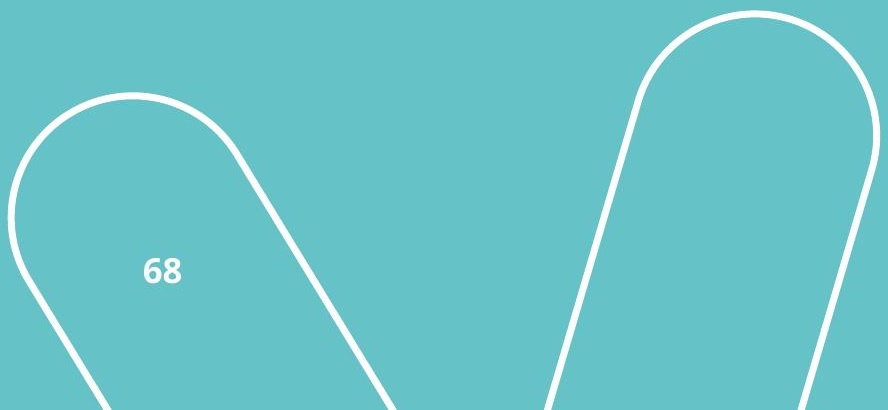


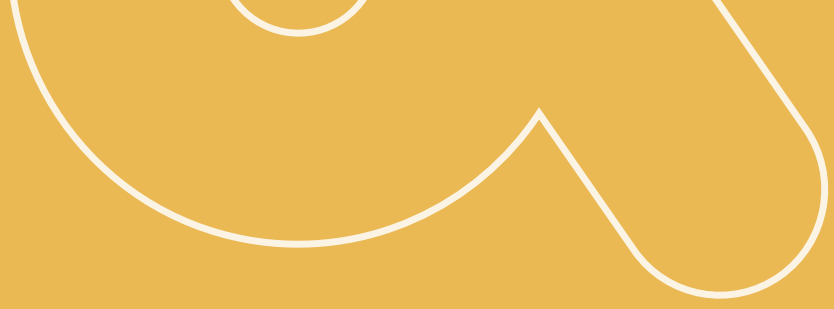

8. MARTÍNEZ DE LEJARZA Y ESPARDUCER, Ignacio; HERNANDIS-ORTUÑO, Bernabé; LAHIGUERA MARCO, Carmen. Representación reticular de los objetivos de un sistema. In: ENCUENTRO EUROPEO DE SISTEMAS, 3., 1994, Valencia. Analles [...]. Valencia: Ajuntament de València, 1994. CD-ROM.

9. MOMOKEY. Modern agriculture. 2013. Available at: https://www.istockphoto. com/es/foto/moderna-de-agricultura-gm163123465-23291533. Access in: 10 Jul. 2019.SCHÖN, Donald A. The reflective practitioner. New York: Basic Books, 1983.

10. ONE MAN'S perspectives. México 2005, 346. 2013. Available at: https://www. flickr.com/photos/24502144@N04/2357766311. Access in: 10 Jul. 2019.

11. ORTIZ, Marienella. La hidroponía crecerá de la mano de la exportación. 2017. Available at: http://www.redagricola.com/pe/la-hidroponia-crecera-lamano-la-exportacion/. Access in: 11 Jul. 2019.

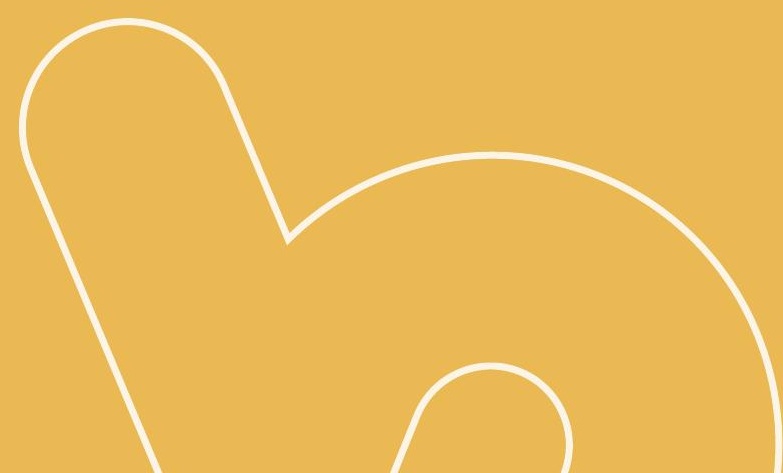

